\title{
内シャント手術の創傷管理に関する検討
}

\author{
田村 雅人 甲藤 和伸塩 津 智之村 章一郎 \\ 高知赤十字病院泌尿器科
}

key words：内シャント手術，ハイドロコロイドドレッシング，創傷管理

〈要旨〉

透析患者においては免疫機能の低下，創傷部の血流の低下など創管理には慎重であるべきであり，今後，糖尿病 患者の増加, 高齢化などにより, さらに慎重な管理を要すると思われる. 近年, 創傷管理においては湿潤環境を保っ た創傷ドレッシングが推奨されるようになってきている. 今回, 191 例の内シャント作製手術で, 創閉鎖はポリディ オキサノン 4-0 で連続皮内縫合を行い, 薄型ハイドロコロイドドレッシングの使用を試みた. 中等度以上の出血, 滲出液を認めても, 良好に吸収され, 被覆が必要と考えられる 48 時間以内にはがれを生じたのは, 3 例のみであっ た. 創部感染, 皮膚の異常を認めた症例はなく, $98.4 \%$ 症例で有用と考えられた. また，創の閉鎖方法の工夫に より, 抜糸の手間や抜糸時の疼痛を軽減することが可能であった， 以上から，安全性，有用性，医療の省力化など の面からも優れた方法であると考えられた.

\section{Management of vascular access surgical wound}

Masato Tamura, Kazunobu Katto, Tomoyuki Shiotsu, Shoichiro Nakamura

Department of Urology, Kochi Red Cross Hospital

Careful management of surgical wounds in uremia patients is necessary because there is suppression of the immunologic response and a bleeding tendency at the surgical site as well as other problems in such patients. In recent years, wound dressing in a wet enviroment is recomended. In the present study, we assessed the clinical benefit of wound management using hydrocolloid dressing after continuous intradermal suture in 191 vascular access operations. In only 3 cases, dressings came off within 48 hours postoperatively. There was no surgical site infection (SSI) or skin problem in any case. In conclusion, this approach to wound management is beneficial from the perspective of preventing SSI, saving labor and being cost-effective.

\section{緒言}

透析患者に抢いては免疫機能の低下 ${ }^{1)}$, 創傷部の出 血傾向 ${ }^{22}$ ，低栄養状態などが予想され，創管理には慎 重であるべきであり，今後，糖尿病患者の増加，高齢 化などにより，さまざまな合併症の増加も予想され， さらに慎重な管理を要すると思われる。

近年，創傷管理においては湿潤環境を保った創傷ド レッシングが推奨されるようになってきている ${ }^{3 \sim 5)}$.

血液透析患者において最も頻繁に行われるのは，内 シャント作製手術である.内シャント作製手術は清潔
手術であるが，血管吻合や人工血管の使用を伴い，手 術部位感染（SSI）を生じれば，重大な障害をひきおこ す可能性がある。

今回，内シャント作製手術に抒いて，創閉鎖の工夫 と, 薄型ハイドロコロイドドレッシング（カラヤヘッ シブ®）の使用を試みたので報告する。

\section{I . 対象と方法}

対象は, 2005 年 9 月から 2007 年 12 月までに, 内 シャント作製手術を施行した 191 例で, 年齢は 19 歳〜 92 歳 (平均 67.4 歳), 性別は男性 110 例, 女性 81 例で

田村 雅人 高知赤十字病院泌尿器科 $\overline{\mathbf{T}}$ 780-8562 高知県高知市新本町 2-13-51

Masato Tamura Tel : 088-822-1201 Fax : 088-822-1056 E-mail : hinyoukika@krchp.jp

〔受付日：2008 年 4 月 22 日, 受理日：2008 年 6 月 27 日〕 


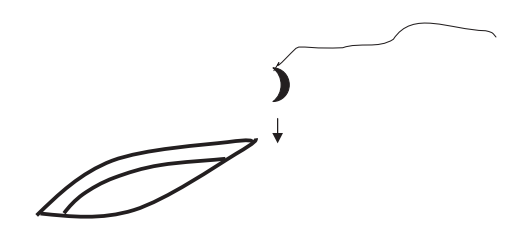

(1)創外から創内に縫合糸を刺入

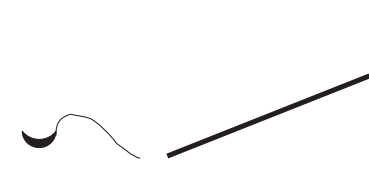

(3)創外に縫合糸を出す

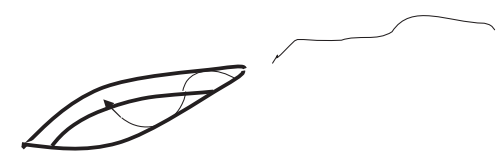

(2)刺入後, 真皮連続縫合

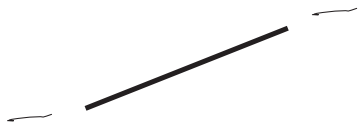

(4)縫合糸を短切する

図 1 創の閉鎖方法

あった．原疾患は糖尿病 91 例，その他 100 例で, 手術 方法は，自己血管内シャント (AVF) 152 例（前腕： 82 例, 时部: 70 例), 人工血管使用 $(A V G) 39$ 例（前 腕 : 6 例, 上腕 : 27 例, 大腿 $: 6$ 例）であった.

創閉鎖方法は創閉鎖前に，創内を生理食塩水で数回 洗浄後，ポリディオキサノン (PDS II $\left.{ }^{\circledR}\right)$ 4-0 で真皮を 連続で縫合し(連続皮内縫合), 両端を創外に出した(図 1). 抜糸は引き抜くか, 創外の糸の端を切断した．創 が皮下組織深くに及ぶ際には，皮下組織を軽くあわせ た後, 同様に創を閉鎖し, 創をハイドロコロイドドレッ シングで被覆した。

抗生剂の投与は清潔手術であるので，原則として AVF, AVG とも術当日投与のみとしたが,「バスキュ ラーアクセスの作製および修復のガイドライン」でも 明記しておらず，AVGの場合や，患者の状態に応じ て主治医判断で 1〜2 日延長した症例もあった.

被創管理方法は，創の感染兆候を毎日観察し，多少 の出血, 滲出液があっても, 感染兆候などがなければ, 1 週間被覆したままとした。被覆材がはがれても 48 時間経過後は，そのまま放置した。原則として，1 週 間〜10 日後，抜糸を行った.

有用性の判定は 1. 被覆材のはがれの有無, 2. 被覆 材のはがれるまでの日数, 3. 創部の出血, 滲出液の程 度（主治医判定で，軽度～重度に分類)，4．創部感染 の有無, 5. 創部〜周囲の皮膚の状態, の項目を調査し た. 48 時間以内にはがれがなく, 創部感染, 皮膚病変 のないものを有用と判定した.

\section{II. 結果}

\section{1 ． 被覆材のはがれの有無}

48 時間までに被覆材がはがれた症例は 3 例 $1.6 \%$ で, 1 例は認知症による自己除去, 2 例が出血・渗出液 によるものであった。

\section{2. はがれるまでの日数}

被覆材のはがれるまでの日数はAVFが $6.92 \pm 0.61$ 日, AVGが, $6.88 \pm 0.56$ 日で有意差はなかった。

\section{3. 創部の出血, 滲出液の程度}

中等度以上の出血・滲出液は AVF 13 例 $(8.6 \%)$, AVG 10 例（25.6\%）に認めたが, 被覆材のはがれた 1 例を除き，被覆材に良好に吸収されていた（図 2，3）。

\section{4. 創部感染}

\section{5. 創部周囲の皮膚病変}

創部感染, 創部周囲皮膚病変は 1 例も認めなかった。 以上より，被覆に必要とされる 48 時間以内にはが れがなく，有害事象を認めなかったものを有用とする と, 有用性は $98.4 \%$ であった。

\section{III. 考 察}

透析患者においては, 免疫機能の低下 ${ }^{1)}$, 創傷部の 出血傾向 ${ }^{2)}$ などが予想され，創管理においては慎重で あるべきであると考えられる，近年，透析患者は，原 疾患として糖尿病患者の増加, 高齢化などにより, 創 傷治癒においてリスクの増加が予想され，さらに慎重 な管理を要すると思われる。

近年, 創傷管理においては湿潤環境, 低酸素, 保温 


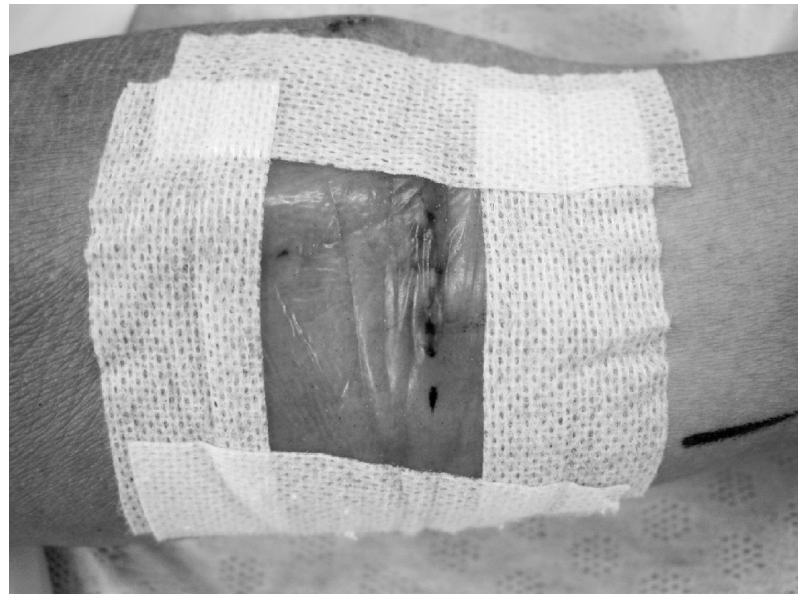

図 2 術後 2 日目の創の状態 (出血, 滲出液の少 ない場合）

が重要で, これらを可能にする創傷ドレッシングが推 奨されるようになってきている沶，また，閉塞性ド レッシング法での溼出液には組織増殖に関与する成与長 因子をはじめ, 多くのサイトカインを含んでいること が知られている ${ }^{6)}$. 湿潤環境を保つドレッシング材の 中でハイドロコロイドドレッシングは粘着性に優れ, 創傷表面の $\mathrm{pH}$ を低く保つ緩衝作用を有し ${ }^{5)}$, さまざ まな部位の創傷に使用可能で, 滲出液の吸収も良好な ため ${ }^{4)}$ ，さまざまな手術の創傷に適応できると考え，

ほかの領域の手術創に用いて有効であるとの報告もあ $り^{7}$, われわれも 2005 年より, 感染創を除いては, 泌 尿器科領域の手術においてもほぼすべての創傷に薄型 ハイドロコロイドドレッシング材を使用している。内 シャント手術は透析患者において最も頻繁に行われる 手術であり，清潔手術であるため手術部位感染（SSI） をおこす可能性は少ないと考えられるが，血管吻合や 人工血管の使用を伴い, SSI を生じれば，重大な障害 をひきおこす可能性があるため, 内シャント手術にも, 慎重な創管理が必要であると考え, 2005 年から湿潤環 境を考慮したドレッシングの使用を始めた。当初はコ ストの面から，フィルムドレッシングを使用していた が, 数\%に出血や溼出液による早期のはがれを経験し たため, 2005 年 9 月から薄型ハイドロコロイドドレッ シングを使用している.

従来，創の閉鎖はナイロン糸による単一結節綘合を 行っていた. 2005 年 9 月から, 創閉鎖前に生理食塩水 50 100 mL で洗浄し, ポリディオキサノン 4-0 で真 皮を連続で縫合し (連続皮内縫合 $)^{8)}$, 両端を創外に出 すこととした，ナイロン糸による単一結節縫合の場合 は，それぞれの縫合糸の抜糸が必要であるが，この方 法だと，糸を引き抜くだけでよく，引き抜けない場合

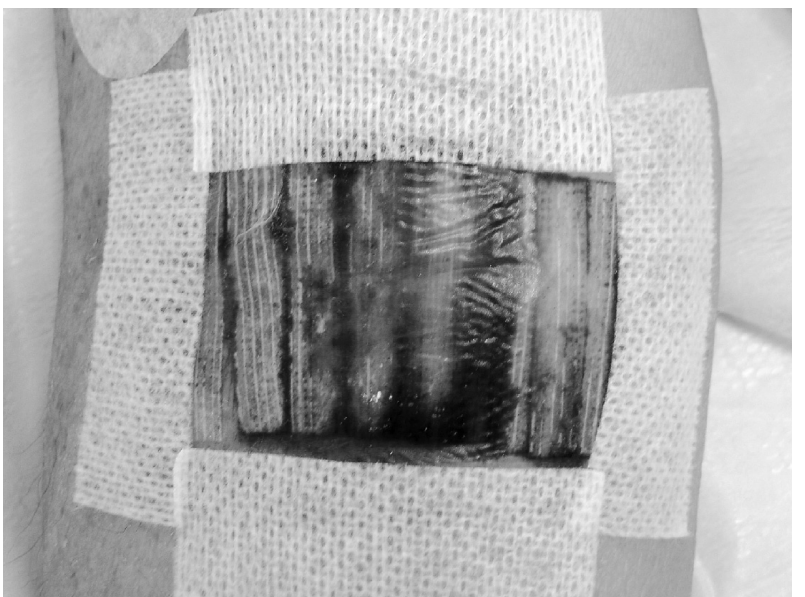

図 3 術後 3 日目の創の状態（出血, 滲出液の多 (場合)

創閉鎖直後も微量な出血あり，テープで創をふさ いだが中等量の出血，滲出液あるも良好に吸収さ れ，7日目まではがれはなかった。

や患者や創の状態により抜糸時期を遅らせたい場合で も, 吸収糸であるため, 約 1 週間後に創外に出た両端 を切るのみで十分である. 抜糸時の省力化, 患者の疼 痛の軽減にもつながると考えている.

今回の検討で, 被覆材のはがれるまでの日数は AVFが $6.92 \pm 0.61$ 日, AVGが, $6.88 \pm 0.56$ 日で, ほとんどの症例で抜糸である 7 日まで被覆材がはがれ ることはなく, 48 時間までに被覆材がはがれた症例は 3 例 $1.6 \%$ のみであった. 中等度以上の出血・滲出液 はAVF 13 例 (8.6\%), AVG 10 例 (25.6\%)に認めた が，1例を除き，被覆材に良好に吸収されていた。

今回の検討では全例で二次ドレッシングとして被覆 材周囲のテープ補強を施行した. 手術部位感染に関す る CDC のガイドラインでは, 術後 24〜 48 時間, 滅菌 材料で保護することが推奨されている（カテゴリー IB $)^{9 \sim 11)}$ ため, 術後早期のはがれを防止するため, 全例 にテープ補強を行った。被覆材やテープ部の皮膚のか ぶれなどの皮膚病変は 1 例も認めなかったが, テープ に対するかぶれなどの可能性もあること，48 時間被覆 できていれば問題ないと考えており, 最近ではAVF の小さな創ではテープ補強せず, AVG などの滲出液 が多くなる場合や導入前で, 手術のみで退院するよう な, 抜系まで医療サイドで, 創の観察ができない場合, はがれにより患者サイドに不安感を与えないため, テープ補強を施行している. CDC ガイドラインや創 傷管理に関するメタアナライシスでは 48 時間以降も 滅菌のまま覆うべきか, シャワーや入浴すべきかのエ ビデンスはないとされている9 . したがって，われわ れも現在のところ, 抜糸の際まで, ドレッシングを敢 
えてはがすことはしていない，術後，早期のシャワー 浴は患者の精神的な QOL の向上につながる反面, シャワー浴によって創の縫合不全やSSI に対する不 安があると思われ, 今後, 48 時間以後のシャワー浴に 対しては課題であると考えられる ${ }^{9)}$.

また，半透明であるため創部の観察も容易で，医師 1 名で行え, 従来のガーゼ交換と比較し, 省力化や医 療廃棄物の減少にもつながると考えられた。

経済的には，欧米では八イドロコロイドドレッシン グの経費は古典的ドレッシングの 38 69\%で経済的 であると報告されている ${ }^{12)}$. ナイロン糸と比較して, PDSの使用で，ポリディオキサノン 4-0 が 1 本約 1,100 円とやや高值である。また，被覆材はAVFで $7.5 \times 5.0 \mathrm{~cm}$ を 1 枚使用しているが, 約 300 円，上腕 AVG で $7.5 \times 5.0 \mathrm{~cm} 1$ 枚, $15 \times 5 \mathrm{~cm} 1$ 枚を使用し, 約 800 円と, 通常の AVF で, 従来の連日のガーゼド レッシングの交換（当院で使用している滅菌ケーパイ ン $\mathrm{M}^{\circledR}$ で 1 枚約 15 円)，フィルムドレッシング（当院 で使用しているテガダーム ${ }^{\circledR} 1624 \mathrm{~W}$ で 1 枚約 40 円）の 使用よりも，コスト高となる。しかし，特に AVG な どでは中等度の出血や滲出液を認めることも $25 \%$ 程 度認められたことより，このような場合，フィルムド レッシングでは 48 時間以内にもかかわらず, 周囲を テープで補強したとしてもはがれが生じる可能性もあ り, 創傷管理の面からは推奨されず, また, 再度ドレッ シングを使用すれば，逆にコスト高になることも考え られ，八イドロコロイドドレッシングのほうが優れて いると考えられた.

\section{結＼cjkstart論}

今回, 191 例の内シャント作製手術で，創閉鎖はポ リデイオキサノン 4-0 で連続皮内縫合を行い，薄型ハ イドロコロイドドレッシング (カラヤヘッシブ®) の使 用を試みた。

中等度以上の出血, 滲出液を認めても, 良好に吸収 され，被覆が必要と考えられる 48 時間以内にはがれ を生じたのは， 3 例のみであった，創部感染，皮膚の
異常を認めた症例はなく, $98.4 \%$ 症例で有用であっ た．また，創の閉鎖方法の工夫により，抜糸の手間や 抜系時の疼痛を軽減することが可能であった。

以上から, 安全性, 有用性, 医療の省力化などの面 からも優れた方法であると考えられた。

なお，本文の要旨は第 52 回日本透析医学会学術集会 において発表した。

\section{文献}

1) Wilson WEC, Kirkpatrick $\mathrm{CH}$, Talmage DW : Suppression of immunologic responsiveness in uremia. Ann Intern Med $62: 1-14,1965$

2) Levis JH, Zucker MB, Ferguson JH : Bleeding tendency in uremia. Blood $11: 1073-1076,1956$

3) Kanzler MH, Gorsulowsky DC, Swanson NA : Basic mechanisms in the healing cutaneus wound. J Dermatol Surg Oncol 12:1156-1164, 1986

4）門田晃一, 公文裕巳：一次縫合創におけるドレッシン グ. 臨床泌尿器科 $56: 707-711,2002$

5）倉本 秋, 瀬尾宏美: 創傷管理の Pros and Cons. 臨 床看護 $25 ： 1840-1849,1999$

6) 田澤賢次, 竹森 繁, 山本克弥, 安田智美: 閉塞性ド レッシングの理論とサイトカイン. Biomed Perspect $7: 53-59,1999$

7）嶋 裕一, 小矢崎直博, 大戸 司: 術後創傷（縫合創） に対する薄型ハイドロコロイドドレッシング（KYD） の臨床効果. 臨牀と研究 $75: 185-195,1997$

8）田井良明：縫合法と縫合糸の選択一形成外科. 外科治 療 $69: 507-513,1993$

9) Guidline for Prevention of Surgical Site Infection, 1999. Infect Control Hosp Epidemiol 20 : 250-278, 1999

10）紺家美津子, 真田弘美：非感染創の管理. EB Nurs 5 : 32-36, 2005

11）野口良輔：手術後の包交は必要か. 臨床泌尿器科 56 : 302-303, 2002

12) Ohlsson P, Larsson K, Lindholm C : A cost-effective study of leg ulcer treatment in primary care: Comparison of saline-gauze and hydrocolloid treatment in a prospective randomized study. Scand J Prim Health Care 12 : 295-299, 1994 